\title{
Ectoparasites from some Myocastor coypus (Molina, 1782) populations (Coypus or Nutria) in Argentina
}

\author{
Ectoparasitas de algumas populaçóes de Myocastor coypus (Molina, 1782) (Coypus ou Nutria) na Argentina \\ Pablo Eduardo Martino ${ }^{1 *}$; Nilda Esther Radman"; María Inés Gamboa ${ }^{1}$; Luis Ernesto Samartino²; \\ Eduardo Joaquín Parrado 3
}

\begin{abstract}
${ }^{1}$ Departamento de Parasitología, Comisión de Investigaciones Científicas de la Provincia de Buenos Aires - CIC, Facultad de Ciencias Veterinarias, Universidad de La Plata - UNLP, La Plata, Argentina

${ }^{2}$ Instituto Nacional de Tecnología Agropecuaria - INTA, Morón, Buenos Aires, Argentina

${ }^{3}$ Servicio Nacional de Seguridad Agroalimentaria - SENASA, Buenos Aires, Argentina
\end{abstract}

Received November 14, 2017

Accepted March 8, 2018

\begin{abstract}
The occurrence of ectoparasites in wild nutria is poorly understood. Fifty-five livetrapped wild nutria (Myocastor coypus) from its indigenous region were examined for ectoparasites after capture from December 2013 to December 2014. The captures came from the Buenos Aires Province, by far the area of the country most densely populated by nutria, characterized as a temperate grassland, which are prime areas for sustained agriculture. Only one species of chewing lice (Pitrufquenia coypus, Marelli, 1932), one flea (Nosopsyllus fasciatus, Bosc, 1800) and one tick (Rhipicephalus sanguineus, Latreille, 1806) were collected. Fourteen percent of the animals were infested and P.coypus, an obligate parasite of the nutria, which was the most prevalent ectoparasite. $N$. fasciatus and $R$. sanguineus occurrence remains controversial as they may or may not be some accidental host species. To our knowledge, this is the first comprehensive and systematic survey of ectoparasites in wild nutria from the southern hemisphere, the indigenous region of this species.
\end{abstract}

Keywords: Myocastor coypus, nutria, ectoparasites, Pitrufquenia coypus.

\section{Resumo}

A ocorrência de ectoparasitas em nutria selvagem é pouco compreendido. Cinquenta e cinco nutria selvagem capturadas (Myocastor coypus) de sua regiáo indígena foram examinados para os ectoparasitas após até captura a partir de dezembro de 2013 a dezembro de 2014. As capturas ocorreram no estado de Buenos Aires, a área mais densamente povoada do país por nutria, caraterizada como uma pastagem temperada, que se tornou área principal para a agricultura sustentável. Uma espécie de piolhos de mastigação (Pitrufquenia coypus, Marelli, 1932), uma pulga (Nosopsyllus fasciatus, Bosc, 1800) e um carrapato (Rhipicephalus sanguineus, Latreille, 1806) foram recolhidos. Catorze por cento dos animais foram infestadas pelo P.coypus, um parasita obrigatório do nutria, sendo o ectoparasita mais prevalente. A ocorrência de $N$. fasciatus e $R$. sanguineus continua controversa, pois podem ou não ser algumas espécies hospedeiras acidentais. Para nosso conhecimento, este é o primeiro estudo abrangente e sistemático de ectoparasitas em nutria selvagem do hemisfério sul, a regiáo indígena desta espécie.

Palavras-chave: Myocastor coypus, nutria, ectoparasitas, Pitrufquenia coypus.

\section{Introduction}

The nutria or coypu (Myocastor coypus) is a hystricomorph rodent native to South America belonging to the Myocastorydae family (SHEFFELS \& SYTSMA, 2007). This large semiaquatic herbivore has been introduced to many countries through meat production

${ }^{*}$ Corresponding author: Pablo Eduardo Martino. Departamento de Parasitología, Comisión de Investigaciones Científicas de la Provincia de Buenos Aires - CIC, Facultad de Ciencias Veterinarias, Universidad de La Plata - UNLP, 60 y 118, CP B1900AVW, La Plata, Argentina. e-mail: pemartino@fcv.unlp.edu.ar and fur-farming. In 1922, Argentineans began raising nutria in captivity and this practice spread worldwide but the species has been traditionally hunted in their natural range as a source of fur and meat. Nutria is not endangered in South America; although, its number and range have been reduced due to loss of habitat by intensive agriculture, road casualty, predation or overhunting (MARTINO et al., 2008; IUCN, 2015).

Nutrias are parasitized by numerous endo and ectoparasites (SCARAMELLA \& MOTTI, 1988; MARTINO et al., 2012), 
but there is a lack of information on free ranging animals. Most of these parasites are of little consequence; some may serve as vectors for zoonotic diseases or cause clinical disease in young individuals (ELTON, 2000; SHEFFELS \& SYTSMA, 2007). The present study was part of a continuing effort by the laboratories engaged in monitoring the health status of this native rodent. Thus, the objective of the present survey was to present data on the prevalence and intensity of external parasites found in wild nutria from its indigenous area.

\section{Materials and Methods}

From December 2013 to December 2014, 55 wild nutria were livetrapped with drive nets and padded box traps (MARTINO et al., 2012) from rural areas of Buenos Aires Province in central Argentina $\left(37^{\circ} 0^{\prime} 0\right.$ "S, $\left.57^{\circ} 9^{\prime} 0^{\prime \prime} \mathrm{W}\right)$. Capture sites were also stocked with rodents, feral dogs and livestock which shifted among pastures.

Traps were set at mudbanks pocked with nutria burrows or at locations which showed signs of movement. Trapping occurred throughout the year and was not seasonally biased. Each nutria was immobolized at the capture site with an intramuscular injection of a combination of $10 / 20 \mathrm{mg} / \mathrm{kg}$ ketamine hydrochloride (Ketalar ${ }^{\circledR}$, Pfizer Inc., New York) and $2 \mathrm{mg}$ of xylazine hydrochloride (Rompun $^{\circledR}$, Bayer, Inc., Ontario).

Captured animals were temporarily or permanently marked to allow individual identification. The age and sex was determined primarily from body length, tooth replacement, and genital development (KINLER et al., 1987), and animals were either immature (juveniles and subadults under 1 year of age) or mature (any adult animal at least 1 year of age). Thorough visual inspection for evidence of ectoparasites was conducted by parting the fur throughout the entire body of the animals and by combing with a flea comb over a white tray to remove larger ectoparasites. Representative specimens were stored in 70\% ethanol and later identified under a stereo-microscope to species-level on the basis of shared morphology with published descriptions (BOERO, 1957; LARESCHI et al., 2011) and comparison with the Department material collection. Voucher specimens were deposited in the reference collection at the Parasitology Department under accession numbers NPM/12/456 to NPM/14/458.

All research was performed in full compliance with established guidelines for use of animals in research (OLFERT et al., 1993). This project was also approved by the Animal Care Committee of the Research Scientific Council (CIC, decree No.578/13), and the protocol for handling nutria was approved by the Buenos Aires Department of Agriculture (Approval No.22230-27/2013-0).

The results were statistically analyzed. Infestation prevalences for each ectoparasite species were compared by the chi-square analysis with Bonferoni adjustment. Mean intensities were compared using the Wilcoxon/Kruskal Wallis test. Prevalence is the percent of nutria infested, and mean intensity of taxon is the mean number of ectoparasites per infested animal, as defined by Bush et al. (1997).

\section{Results}

Three taxa of ectoparasites were identified from 11 out of the 55 nutria. The ectoparasites collected, prevalence, intensity and date of collection are shown in Table 1. The ectoparasites were $P$. coypus, $N$. fasciatus and $R$. sanguineus. Total infested animals $(08 / 55,14.5 \%)$ were not significantly prevalent ( $p>0.05)$. Similarly, there was no difference between sexes or ages among the infested animals $(p>0.05)$. No seasonal distribution pattern was noted among the infestations except for the moderately seasonal tendency during the colder months, although not significantly ( $p>0.05)$. There was limited variation in the diversity of the ectoparasites. P. coypus was the most prevalent parasite, with up to 19 specimens collected from 7 hosts $(p>0.05)$, and it had the highest mean intensity ( $\mathrm{p}>0.05)$. Of these 7 nutrias, 2 young females were also infested by $N$. fasciatus and $R$. sanguineus.

Conversely, $N$. fasciatus and $R$. sanguineus were both uncommon, with few specimens found on two and one hosts, respectively.

Mild focal cutaneous inflammation associated with tick bites was observed in only one animal, but no external lesions were noted during the removal of representative ectoparasites in the rest of the accessions. All nutria significantly appeared in healthy conditions based on a brief physical examination, except one debilitated adult female infested with $P$. coypus which had cutaneous myiasis by larvae of the fly Dermatobia hominis (Díptera: Cuterebridae) $(\mathrm{p}<0.001)$.

\section{Discussion}

Although scarcely reported, nutria also host a wide variety of internal and external parasites (FELDHAMER et al., 2003; SHEFFELS \& SYTSMA, 2007; MARTINO et al., 2012).

In this survey, few species of ectoparasites were recovered, and $P$. coypus was the only identified true parasite of nutria (DURDEN \& LLOYD, 2002; RIVEROLA, 2008). P. coypus, a chewing

Table 1. Ectoparasites collected from 55 wild nutria from rural areas of Buenos Aires Province, in central Argentina.

\begin{tabular}{|c|c|c|c|}
\hline Ectoparasite collected & $\begin{array}{c}\text { Prevalence \% } \\
(95 \% \mathrm{CI})\end{array}$ & $\begin{array}{c}\text { Intensity } \\
\text { (mean-range) }\end{array}$ & $\begin{array}{c}\text { Date of collection } \\
\text { (month - year) }\end{array}$ \\
\hline P. coypus & $12.7 \%(8.3-15.1)$ & $6.11-19$ & $05,07,08,10,11-2014$ \\
\hline$N$. fasciatus ${ }^{2}$ & $3.6 \%(0.9-5.5)$ & $3.32-4$ & $10,11-2014$ \\
\hline R. sanguineus ${ }^{\mathrm{b}}$ & $1.8 \%(0.6-2.1)$ & $1.60-1$ & $10-2014$ \\
\hline Dermatobia hominis ${ }^{c}$ & $1.8 \%(0.5-2.1)$ & $>20$ larvae & $11-2014$ \\
\hline
\end{tabular}

Notes: $95 \%$ CI: ninety-five percent confident intervals; ${ }^{A}$ one of these two animals also had P. coypus; ${ }^{B}$ this animal also had $P$. coypus; ${ }^{C}$ this animal also presented P.coypus. No mean intensity nor range were done for the fly larvae infestation. 
louse belonging to the Gyropidae family, is fairly specific in its host preferences and was first described among South American nutria (CASTRO et al., 1987). It has also been reported in Brazil (VALIM, 2010), Louisiana (SHEFFELS \& SYTSMA, 2007), and Great Britain (NEWSON \& HOLMES, 1968). Prevalences of infestation in literature range from 5 to $100 \%$ (NEWSON \& HOLMES, 1968; SHEFFELS \& SYTSMA, 2007). The overall prevalence infestation in our survey was low (12.7\%), with P. coypus found located close to the skin, especially in the face and chest, but without causing any apparent skin lesions (RIVEROLA, 2008). Intensity of infestation was not correlated with body size or sex and ranged from 1 to 19 P. coypus /animals; meanwhile, peak infestation during winter occurred in 4 out of 7 animals.

Newson \& Holmes (1968) reported that P. coypus were found on coypus of all ages and both sexes throughout the year, but Feldhamer et al. (2003) reported that season appeared to modulate the rate of infestation, with the highest incidence occurring in late winter. Perhaps conditions of the host pelage or of the microhabitats inside the host nests may influence off-host survival and reproduction for the parasite (DURDEN et al., 2004).

The northern rat flea $(N$. fasciatus) and the brown dog tick ( $R$. sanguineus) were found here in only one accession each, but more field-based studies are needed to clarify if the occurrence of these ticks in such hosts might be considered accidental or not (SCARAMELLA \& MOTTI, 1988; SHEFFELS \& SYTSMA; 2007). None of these species is particularly restricted in host selection and they were commonly collected from different localities of South America (BOERO, 1957; CASTRO et al., 1987; RUIZ et al., 2003). Other ticks occurrences in this host on South América are already described in the Neotropical tick literature as their habitat covers widely different regions. In fact, Amblyomma dubitatum was described by Estrada Peña et al. (2002) from engorging nymphs specimens of both sexes collected in 1999 on nutria in Jundiai (São Paulo, Brazil, 2311'S; 4652'W). Although specimens of A. dubitatum were collected on several other mammal species, capybara (Hydrochoerus hydrochaeris) is the principal host for all parasitic stages of this tick (NAVA et al., 2010). Likewise, The National Tick Collection of the Faculty of Veterinary Medicine of the University of Sáo Paulo contains nine engorged nymphs of nutria; all these records were from the state of São Paulo and the nymphs were identified as Amblyomma cooperi only after they molted to the adult stage in the laboratory (LABRUNA et al., 2004). The adult stage of $A$. cooperi has been repeatedly reported on capybaras, which is incriminated to be its primary host, but the results of larval and nymphal infestation on another hosts (either birds and mammals) suggest that they could be potentially infested by $A$. cooperi immature stages in nature (LABRUNA et al., 2002, 2004). Although on a wide basis the distribution of both tick species appears to be sympatric they colonize different ecological niches (NAVA et al., 2010).

The relatively infrequent occurrence of ectoparasitism on nutria may been attributed to its semi-aquatic existence and grooming habits, as it occurs with other large aquatic furbearers (SERFASS et al., 1993; WHITAKER, 2006). In the literature, the external parasitic fauna of the nutria usually include lice, fleas and several tick species (NEWSON \& HOLMES, 1968; WILLNER,
1982), although they do not exhibit parasitism (SHEFFELS \& SYTSMA, 2007).

\section{Conclusions}

Despite the restricted geographical area investigated and due to the low parasite prevalences and the mean good condition of the studied animals herein, parasitic disease may not be a major factor in this wild population. More intensive collection procedures may be necessary to adequately assess the ectoparasite fauna on nutria and its seasonal tendencies.

\section{Acknowledgements}

Funding for this study was provided by CIC and INTA. Logistic support during field operations was provided by the Buenos Aires Department of Agriculture and was coordinated by their staff.

\section{References}

Boero JJ. Las garrapatas de la República Argentina (Acarina: Ixodoidea). Buenos Aires: EUDEBA Dpto. Edit. Univ; 1957.

Bush AO, Lafferty KD, Lotz JM, Shostak AW. Parasitology meets ecology on its own terms: Margolis et al. revisited. J Parasitol 1997; 83(4): $575-$ 583. http://dx.doi.org/10.2307/3284227. PMid:9267395.

Castro D, Mauri R, Cicchino A, Mosquera S. Ectoparasitos de roedores de la Provincia de Buenos Aires, Argentina (Acarina, Anoplura, Mallophaga y Suctoria). Rev Soc Ent Arg 1987; 44(3): 317-327.

Durden LA, Lloyd JE. Lice (Phthiraptera). In: Mullen G, Durden L. Medical and veterinary entomology. 2nd ed. San Diego: Academic Press; 2002. p. 56-79. http://dx.doi.org/10.1016/B978-012510451-7/50006-2.

Durden LA, Polur RN, Nims T, Banks C, Oliver J Jr. Ectoparasites and other epifaunistic arthropods of sympatric cotton mice and golden mice: comparisons and implications for vector-borne zoonotic diseases. $J$ Parasitol 2004; 90(6): 1293-1297. http://dx.doi.org/10.1645/GE-333R. PMid:15715219.

Elton CS. The ecology of invasions by animals and plants. 2nd ed. Chicago: The University of Chicago Press; 2000.

Estrada Peña A, Venzal JM, Guglielmone AA. Amblyomma dubitatum Neumann: description of nymph and redescription of adults, together with the description of the immature stages of $A$. triste Koch. Acarologia 2002; 42(4): 323-333.

Feldhamer GA, Thompson BC, Chapman JA. Introduced animals: Nutria: (Myocastor coypus). In: Feldhamer GA, Thompson BC, Chapman JA. Wild mammals of north america: biology, management, and conservation. 2nd ed. Baltimore: Johns Hopkins University; 2003. p. 1136-1138.

International Union for Conservation of Nature and Natural Resources IUCN. Red list of threatened species. Version 2015.3 [online]. Cambridge; 2015 [cited 2015 Aug 30]. Available from: http://www.iucnredlist.org

Kinler NW, Linscombe G, Ramsey PR. Nutria. In: Novak M, Baker J, Obbard ME, Malloch B. Wild furbearer management and conservation in North America. Ontario: Ministry of Natural Resources; 1987. p. 327-343.

Labruna MB, Paula CD, Lima TF, Sana DA. Ticks (Acari: Ixodidae) on wild animals from the Porto-Primavera Hydroelectric power station area. 
Brazil Mem Inst Oswaldo Cruz 2002; 97(8): 1133-1136. http://dx.doi. org/10.1590/S0074-02762002000800012. PMid:12563479.

Labruna MB, Pinter A, Teixeira RH. Life cycle of Amblyomma cooperi (Acari: Ixodidae) using capybaras (Hydrochaeris hydrochaeris) as hosts. Exp Appl Acarol 2004; 32(1-2): 79-88. http://dx.doi.org/10.1023/ B:APPA.0000018228.05088.26. PMid:15139274.

Lareschi MA, Autino A, Díaz M, Barquez RM. Taxonomy and distribution of Nonnapsylla Wagner, 1938 (Siphonaptera, Stephanocircidae, Craneopsyllinae). J Parasitol 2011; 97(5): 954-955. http://dx.doi. org/10.1645/GE-2738.1. PMid:21612417.

Martino PE, Radman N, Parrado E, Bautista E, Cisterna C, Silvestrini $\mathrm{M}$, et al. Note on the occurrence of parasites of the wild nutria (Myocastor coypus). Helminthologia 2012; 49(3): 164-168. http://dx.doi.org/10.2478/ s11687-012-0033-y.

Martino PE, Sassaroli JC, Calvo J, Zapata J, Gimeno E. A mortality survey of free range nutria (Myocastor coypus). EurJ Wildl Res 2008; 54(2): 293-297. http://dx.doi.org/10.1007/s10344-007-0146-7.

Nava S, Venzal JM, Labruna MB, Mastropaolo M, González E, Mangold AJ, et al. Hosts, distribution and genetic divergence (16S rDNA) of Amblyomma dubitatum (Acari: Ixodidae). Exp Appl Acarol 2010; 51(4): 335-351. http://dx.doi.org/10.1007/s10493-009-9331-6. PMid:20084537.

Newson RM, Holmes RG. Some ectoparasites of the coypu (Myocastor coypus) in eastern England. J Anim Ecol 1968; 37(2): 471-481. http:// dx.doi.org/10.2307/2960.
Olfert ED, Cross BM, McWilliam AA. Guide to the care and use of experimental animals. 2nd ed. Ottawa: CCAC Canadian Council on Animal Care; 1993.

Riverola NE. Contribution à l'étude anatomique du ragondin (Myocastor coypus Molina) [dissertation]. Toulouse: Ecole Nationale Veterinaire; 2008.

Ruiz MF, Orcellet VM, Iriarte JA, Carrera M, Guglielmone AA. The presence of Rhipicephalus sanguineus (Latreille, 1806) and Amblyomma tigrinum Koch, 1844 (Acari: Ixodidae) in southern Argentina. Syst Appl Acarol 2003; 8(1): 89-91. http://dx.doi.org/10.11158/saa.8.1.10.

Scaramella D, Motti G. Allevamento del castorino. 1st ed. Bologna: Edagricole Publishing; 1988.

Serfass TL, Peper RL, Whary MT, Brooks RP. River otter (Lutra canadensis) reintroduction in Pennsylvania: prerelease care and clinical evaluation. $J$ Zoo Wildl Med 1993; 24(1): 28-40.

Sheffels T, Sytsma M. Report on nutria management and research in the Pacific Northwest. Portland: Center for Lakes and Reservoirs, Portland State University; 2007.

Valim MP. Sistemática e análise cladistica das espécies do genero Gyropus Nitzsch Phthiraptera, Amblycera, Gyropidae) [dissertation]. Belo Horizonte: Universidade Federal de Minas Gerais; 2010.

Whitaker JO Jr. Ectoparasites of North American aquatic rodents and comparison to European forms. Acarina 2006; 14(2): 137-145.

Willner GR. Nutria (Myocastor coypus). In: Chapman JA, Feldhamer GA. Wild mammals of North America. Baltimore: John Hopkins University Press; 1982. p. 1059-1076. 